\title{
Limited Access to the Courts: An Appraisal of Fee Systems
}

Although the constitutionality of court fees ${ }^{1}$ has been extensively discussed in recent years by courts and commentators, ${ }^{2}$ and although every state $^{3}$ conditions access to its courts on the payment of fees, ${ }^{4}$ no systematic attempt has been made to determine either the desired or the actual effect of these fees on courts or on litigants. ${ }^{5}$

1 This comment considers only fees assessed in private civil actions in state and federal courts of general jurisdiction. Its scope includes all fees related to prosecution of an action through trial and execution of judgment, but excludes fees related to appeals. For a discussion of fees and costs in criminal cases see Comment, Charging Costs of Prosecution to the Defendant, 59 GEO. L.J. 991 (1971); Note, Kansas Court Costs: The Quality of Mercy is Strained, 9 WAsHBURN L.J. 87 (1969); Note, Criminal Costs Assessment in Missouri-Without Rhyme or Reason, 1962 WASH. U.L.Q. 76.

2 Commentators have frequently argued that court fees for indigents are unconstitutional. E.g., Abram, Access to the Judicial Process, 6 GA. L. REv. 247 (1972); Goodpaster, The Integration of Equal Protection, Due Process Standards, and the Indigent's Right of Free Access to the Courts, 56 Iown L. REv. 223 (1970); Note, Litigation Costs: The Hidden Barrier to the Indigent, 56 GFO. L.J. 516 (1968) [hereinafter cited as Litigation Costs]; Note, $A$ First Amendment Right of Access to the Courts for Indigents, 82 YALE L.J. 1055 (1973). But see Jacoby, Legal Aid to the Poor, 53 HARv. L. REv. 940 (1940). Some commentators have suggested that indigents should be excused from payment of all fees. Silverstein, Waiver of Court Costs and Appointment of Counsel for Poor Persons in Civil Cases, 2 VALP. L. REv. 21 (1968); Willging, Financial Barriers and the Access of Indigents to the Courts, 57 GEo. L.J. 253 (1968); Note, Access to the Civil Courts: The Need for Continuing Reform, 37 ALBANY L. REv. 135 (1972).

The Supreme Court, however, has found constitutional defects in court fees only under limited circumstances. See Ortwein v. Schwab, 410 U.S. 656 (1973); United States v. Kras, 409 U.S. 434 (1973); Boddie v. Connecticut, 401 U.S. 371 (1971); Note, Constitutionality of Cost and Fee Barriers for Indigent Litigants: Searching for the Remains of Boddie after a Kras-Landing, 48 IND. L.J. 452 (1973). But see Lee v. Habib, 424 F.2d 891 (D.C. Cir. 1970); Earls v. Superior Court, 6 Cal. 3d 109, 490 P.2d 814, 98 Cal. Rptr. 302 (1971). See generally Michelman, The Supreme Court and Litigation Access Fees: The Right to Protect One's Rights (pt. 1), 1973 DukE L.J. 1153 [hereinafter cited as Access Fees]; Michelman, Foreword: On Protecting the Poor Through the Fourteenth Amendment, 83 HARv. L. Rev. 7 (1969) [hereinafter cited as Protecting the Poor].

3 Unless the context clearly indicates otherwise, "state" in this comment includes the federal government.

4 See Saari, Open Doors to Justice-An Overview of Financing Justice in America, 50 J. AM. JUD. Soc'Y 296 (1967).

6 But see, e.g., Carroll v. United States, 320 F. Supp. 581, 582 (S.D. Tex. 1970); Ashley v. Superior Court, 82 Wash. 2d 188, 192, 509 P.2d 751, 755 (1973); 1963 ALASKA ADM. DrR. CTS. ANN. Rep. 65, 66; K. LaU, JuRy Fees in Crvil CASes (1956); P. MANLEX, District Court Finance in New Mexico (1964); New York Temporary Commission on the State CoURT SYsTeM, . . . AND JUSTICE For ALr, pt, 1, at 70-73 (1973); NEW YORK TEMPPORARY 
After presenting a descriptive survey of existing fee systems, ${ }^{6}$ this comment identifies their principal goals and examines the extent to which they achieve those goals. In conclusion, the comment suggests modifications that would increase the effectiveness of court fee systems.

\section{Current Fee Systems}

\section{A. Development of Multiple and Single Fee Systems}

Multiple fee schedules derive from an early form of court finance in which certain officers of the court, such as bailiffs, clerks, and sheriffs, were compensated by the fees they collected from litigants for performing official duties. ${ }^{7}$ Current multiple fee systems reflect this derivation by assessing fees primarily for services performed by officers who were formerly fee compensated, ${ }^{8}$ while fees are generally not assessed

Commission on the Courts, I Pretiminary Report 42 (1954); North Carolina Courts COMMISSION REPORT 35-40 (1965).

6 Fee systems are composed of two elements: the structure of the system-what fees are assessed and who pays them-and the magnitude of fees imposed within that structure. This comment focuses primarily on the structure of fee systems, not on the magnitude of fees.

7 Abuse of this system has led to its abolition in most areas. See H. Morris, ThE Counry FEe SYSTEM: A NEED FOR REVISION 3 (1971); Moore, The Fee System of Public Administration, 9 OKLA. ST. B.J. 52 (1938).

8 The following fee schedule for the district courts of Louisiana illustrates this emphasis:

The clerks of the several district courts shall be entitled to demand and receive the following fees of office, and no more, in civil matters:

For indorsing, registering, and filing petition, twenty-five cents.

For indorsing, registering, and filing supplemental or amended petition, twenty-five cents.

For indorsing, registering, and fling answer, twenty-five cents.

For indorsing, registering, and filing amended answer, twenty-five cents.

For copying all instruments of writing or pleadings, not otherwise provided for, each one hurdred words, including seal and certificate thereto, thirty-five cents.

For issuing citations, with seal and certificate, one dollar.

For issuing copy of citation, with seal and certificate, fifty cents.

For issuing writ of attachment, with seal, one dollar.

For issuing copy of writ of attachment, with seal and certificate, fifty cents.

For issuing writ of fieri facias, with seal, two dollars.

For issuing order of seizure and sale or executory process, with seal, two dollars.

For issuing writ of sequestration, with seal, one dollar.

For issuing copy of writ of sequestration, with seal and certificate, fifty cents.

For issuing venire facias in each case in which a jury may be prayed for and ordered, with seal, one dollar.

For copy of venire facias, with seal and certificate, when ordered and issued, fifty cents.

For swearing jury, one dollar.

For swearing each witness, twenty-five cents.

For entering final judgment in full on the minutes, fifty cents and thirty-five cents per hundred words.

For simply entering statement of rendition of final judgment, without copying it in the minutes, fifty cents.

For every interlocutory judgment entered on the minutes of the court no matter how many parties, fifty cents.

For each order of court entered on the minutes of courts not otherwise provided 
for services traditionally financed by the state, such as provision of a courtroom and a judge. In a pure multiple fee system, a litigant would be assessed a separate fee for each service provided by the court system. No existing fee system, however, uses this pure form.

The cost of administering a multiple fee system ${ }^{9}$ has prompted many states $^{10}$ to adopt single fee systems. ${ }^{11}$ Under a pure single fee system, one charge would cover all court services. Although many existing court fee systems approach the pure system, ${ }^{12}$ each varies from it in some way. Almost all jurisdictions charge separate fees for service of process, ${ }^{13}$ jury trial, ${ }^{14}$ transcripts, ${ }^{15}$ and preparation of the record for appeal, ${ }^{16}$ and several states assess a fee upon entry of judgment. ${ }^{17}$ Systems also vary in

for, twenty-five cents.

For copies of same, with seal and certificate, fifty cents.

For filing and registering returns on all writs, twenty-five cents.

For issuing notice to creditors of insolvents to attend meetings, with seal and certificate, one dollar.

For issuing copy of notice to creditors of insolvents, with seal and certificate, fifty cents.

LA. Stat. ANn. ch. 13, \$ 841 (1968).

9 See text at note 60 infra.

10 E.g., Legislative Commission of the Nevada Legislative Counser Bureau, Nevada's COURT STRUCTURE 37 (1968) (declaring "these detailed small fees merely create additional bookkeeping . . . and could ... be replaced by a single filing fee"). See also NoRTH CAROLINA COURTS SYSTEM, REPORT 38 (1968) (noting that, "as a result of this [multiple fee] system, the items for which fees are charged continues to expand, the amount of the fees continues to increase, and the system becomes increasingly cumbersome and confusing").

11 Single fees generally range from $\$ 10.00$ to $\$ 40.00$. See statutes cited at notes 18,19 \& 22 infra. The fee often varies with the type of action, e.g., OKLA. STAт. ANN. tit. 28, $\$ 152$ (Supp. 1973) (civil actions, $\$ 20.00$; marital actions, $\$ 15.00$; forcible entry and detainer, $\$ 10.00)$; the amount of the claim, e.g., FLA. STAT. ANN. $\$ 34.041$ (1974) (on filing claim less than $\$ 100, \$ 3.50$; on filing claim greater than or equal to $\$ 100$ but less than $\$ 1000$, $\$ 10.00$; on filing claim greater than or equal to $\$ 1000, \$ 15.00 \mathrm{fee})$; and the size of the judgment, e.g., Colo. REv. STAT. ANN. \$ 56-5-3 (Supp. 1969) (when case proceeds to trial and a money judgment greater than $\$ 5000$ is recovered, additional fee assessed, ranging from $\$ 10.00$ for judgments over $\$ 5000$ but less than $\$ 10,000$, to $\$ 90.00$ for judgments of at least $\$ 50,000$ with an additional assessment of $\$ 2.00$ for every $\$ 1000$ over $\$ 50,000$ ). Many jurisdictions impose additional fees on litigants to fund noncourt services. See, e.g., ALA. CODE tit. 11, \& 83(1) (Supp. 1973) (\$2.00 "fair trial tax" to finance fund for payment of indigents' litigation expenses); IDAHo CODE $\$ 75-213$ (1973) (\$4.00 tax to fund state code revision commission); TEx. REv. Crv. STAT. art. 1702a-1 (Supp. 1974) (\$2.50 fee to support county law library). One study has commented that "[t]hese assessments are difficult to defend in principle, since the court system is taxing certain persons brought before the court for [services] . . . which, theoretically, benefit everyone." 1972 Jud. CouncuL of CALIF. ANN. REP., at A-109.

12 E.g., OrLa. Stat. ANN. tit. 28, §§ 152 et seq. (Supp. 1973) (\$20.00 single fee); TEx. Rev. CIv. STAT. art. 3930(b) (Supp. 1974) (\$10.00 fee in county courts).

13 E.g., Mrch. STAt. ANN. § 27A.2558 (Supp. 1974) ( $\$ 3.00$ plus traveling costs).

14 E.g., Conn. Gen. Stat. ANn. § 52-258 (Supp. 1973) (\$40.00); Mo. ANn. Stat. § 494.160 (1949) $(\$ 12.00)$.

15 E.g., MICH. STAT. ANN. \& 27A.2543 (Supp. 1974) (25\& per folio).

16 E.g., id. \& 27 A.2546 ( $\$ 1.00$ per page).

17 E.g., id. \& 27A.2528 (\$10.00). 
the allocation of fees between the parties ${ }^{18}$ and in the timing of fee assessment. ${ }^{10}$

\section{B. Common Characteristics of Multiple and Single Fee Systems}

Multiple and single fee systems have several characteristics in common. First, courts are heavily subsidized under both fee systems. ${ }^{20}$ Compared with the cost of providing court services, ${ }^{21}$ court fees are nominal. ${ }^{22}$ Second, since the structure of a fee system and the magnitude of the fees imposed are generally established by statute, ${ }^{23}$ legislative action is required to create new fees or to modify existing ones. ${ }^{24}$ Third,

18 In several jurisdictions, the plaintiff pays a portion of the total fee on-filing a complaint, and the defendant pays the balance on filing an answer. E.g., ARrz. REv. STAT. ANN. \$ 12-311 (Supp. 1973) ( $\$ 20.00$ on filing complaint, $\$ 10.00$ on filing answer); Colo. REv. STAT. ANN. \$ 56-5-1 (Supp. 1969) (\$25.00 on filing complaint, \$12.50 on filing answer).

19 For example, only a portion of the fee might be assessed on filing a complaint, with the remainder due only if the case proceeds to trial. E.g., S.D. Comprlmd LAws ANN. $\S 16-10-8$ (Supp. 1973) ( $\$ 5.00$ on filing, $\$ 3.00$ on trial; if jury trial, $\$ 5.00$ on filing, $\$ 5.00$ on trial).

20 It can be argued that civil litigants are not subsidized by taxpayers, but by those who pay fines and forfeit bail. In many areas, total revenues generated by courts exceed total costs. In California, for example, the operating cost of all trial courts for fiscal 1972 was $\$ 130.7$ million, while revenues of the system were $\$ 161.5$ million. 1972 Jud. CounciL of CAL. ANN. REP., at A-13.

21 Accurately estimating the extent to which fees recover costs (the "recovery ratio") is difficult. The necessary data on fee income and civil court costs are often unavailable. Court financial statements usually aggregate income from all sources, such as civil fees, criminal cost assessments, fines, and bail forfeitures, while operating statements rarely categorize expenses into civil and criminal components. In one jurisdiction where suffcient information is available to calculate the ratio, it appears that fees recover less than eight percent of costs. 1971 MAss. Sur. JUd. CT. ANN. REP. 47-53 (Superior Court of Suffolk County). These figures probably underestimate the recovery ratio because the government, as litigant, customarily does not pay fees. Thus, a portion of the government subsidy can be considered a payment in lieu of fees. See also NEW York TEMPORARY COMMIssion on THE CouRTs, supra note 5 at 21.

22 When no appeal is taken, total fees rarely exceed $\$ 50.00$. E.g., Colo. REv. STAT. ANN. § 56-5-1 (Supp. 1969) (\$37.50 plus variable judgment fee, district court); ConN. GEN. STAT. ANN. § 52-259 (Supp. 1973) (\$45.00, entry fee, superior court); IowA Code ANN. § 606.15 (Supp. 1974) (\$9.00, average case, district court); MAss. ANN. LAws ch. $262 \S 4$ (1968) (\$5.00, superior court). The policy of assessing only nominal fees for civil litigants is to be contrasted with the policy of many jurisdictions of assessing convicted criminal defendants the actual costs of their prosecution. See Aldisert, A Metropolitan Court Conquers Its Backlog (pts. 1-3), 51 J. AM. JUD. Soc'y 202, 247, 298 (1968).

23 See statutes cited at notes 8 \& 11-19 supra. Several legislatures have delegated to courts the power to determine fee structures and amounts. E.g., ALASKA STAT. \$ 22.05.020 (1971); DeL. Code ANN. tit. 10, § 8708 (Supp. 1970) (chancery).

24 Court service levels are effectively determined by legislative appropriations. See Hazard, McNamara \& Sentilles, Court Finance and Unitary Budgeting, 81 Yale L.J. 1286 (1972). Although legislative decisions on court funding are generally unreviewable, courts have successfully brought writs of mandamus to compel adequate appropriations in a few instances of inadequate funding. See Wayne Circuit Judges v. Wayne County, 383 
most systems require prepayment of fees unless security has been posted. ${ }^{25}$ Fourth, the prevailing party usually recovers any fees he has paid from the losing party. ${ }^{26}$ Fifth, most states have in forma pauperis statutes or other special provisions waiving the security deposit or fee prepayment requirements for indigents. ${ }^{27}$

\section{Cruteria of Effective fee Systems}

Legislative documents, ${ }^{28}$ the literature applying economic analysis to the courts, ${ }^{29}$ and general theories of politics and economics ${ }^{30}$ indicate that an effective fee system should be directed toward three general goals: allocation and conservation of resources, consonance with state social policies, and administrative feasibility. The effectiveness of a particular fee system can be measured by its success in achieving these goals.

Fees, like all prices, can be used to allocate and conserve resources. The basic resources used to produce court services, principally labor, could be used alternatively to produce other goods and services. In the market, consumers make their preferences known through their willing-

Mich. 10, 172 N.W.2d 496 (1969), modified on rehearing, 386 Mich. 1, 190 N.W.2d 228 (1971); Commonwealth ex rel. Carroll v. Tate, 442 Pa. 45, 274 A.2d 193 (1971).

26 E.g., Mrch. STAT. ANN. \$ 27A.2528(1) (Supp. 1974).

28 E.g., N.J. REv. STAT. \$ 22A:2-8 (1969); Wis. STAT. ANN. \$ 271.04(2) (1958).

27 Silverstein, supra note 2, at 33. In some states, all fees are waived; in others, fees are waived for only a limited number of services. $I d$. Moreover, some statutes allow a state to assess waived fees if the indigent succeeds in litigation or later ceases to be indigent. Litigation Costs, supra note 2, at 524 n.55.

28 See, e.g., 1972 New York LEg. ANN. 1, 32; LegisLative Commlssion of the Neyada Lfgislative Counsel BuREau, supra note 10 at 37; Rhode Island Special Commission to STUDY AND REVISE THE JUDICIAL SYSTEM, INTERIM REPORT 12 (1959); authorities cited note 5 supra.

29 See, e.g., R. POSNER, ECONOMic ANalysis of LAW 320-56 (1972); Landes, An Economic Analysis of Courts, $14 \mathrm{~J}$. LAW \& Econ, 61 (1971); Posner, An Economic Approach to Legal Procedure and Judicial Administration, 2 J. LEg. Studies 399 (1973); Posner, Taxation by Regulation, 2 BEr. J. OF Econ. \& MGMr. Scr. 22 (1971).

30 See, e.g., Brownlee, User Prices vs. Taxes in Public Finance-Nerds, Sources, and Urilizations 421 (1961); Round Table, Taxes and User Charges in Government Finance, 1955 PRoc. NAT'L TAX Assoc, 139 (1956); Brownlee, The Economics of Government Expenditures: Using Market Mechanisms in Making Government Expenditure Decisions, 49 AM. ECON. REv. 359 (Proceedings 1959); Vandermuelen, Five Canons for Setting State Fees, 4 W. Econ. J. 216 (1966); See also R. Musgrave, The Theory of Public Finance (1959); Backman \& Kurnow, Pricing of Government Services, 7 NAT'L TAX J. 121 (1954); Davies, Financing Urban Functions and Services, 30 LAW \& ConTEMP. ProB. 127 (1965); Robinson, Benefits Received Financing in the Federal Fiscal System, 17 NAT'L TAX J. 241 (1964); Stockfisch, Fees and Service Charges as a Source of City Revenues: A Case Study of Los Angeles, 13 NAT'L TAX J. 97 (1960); Stockfisch, The Outlook for Fees and Service Charges as a Source of Revenue for State and Local Governments, 1967 Proc. NaT'z TAx Assoc. 86 (1968); Ture, An Appraisal of New Revenue Sources, 25 NaT'L TAx J. 451 (1972); Vandermuelen, Reform of a State Fee Structure, 17 NAT'L TAX J. 394 (1964). 
ness to pay more for particular uses of resources; producers react by allocating resources to satisfy these demands. ${ }^{31}$ By establishing fees (as producers establish prices) and by reacting to consumer demand (as producers react), states can use the market mechanism to provide a proper allocation of resources to courts.

For example, private arbitration might be able to resolve a particular class of dispute at a lower real cost than the courts. Resources would thus be misallocated if courts were used to resolve these disputes instead of arbitration. If the fee for the courts and the price of arbitration each reflect the respective costs of those services, a proper allocation of resources will occur as consumers select the less costly alternative of arbitration. $^{32}$ But if government sets the price of court services below cost, resources would be misallocated.

Fees may also help court administrators allocate resources within the court system. For example, although an administrator may believe that funds should be spent to relieve court delay, litigants may actually prefer delay. ${ }^{33}$ One commentator has suggested that court fees, through the market mechanism, can be used to determine litigants' preferences by indicating whether they are willing to pay the cost of reducing delay. ${ }^{34}$

In addition to providing a basis for allocating resources to the courts, an effective fee system can also deter waste of those resources. ${ }^{35}$ Court fees, like all prices, motivate consumers to compare the benefits they

31 The scarce supply of all resources necessitates their allocation among goods and services, and that allocation is accomplished through the price component of the market mechanism. Efficient allocation occurs only in a perfectly competitive economy, where transactions are costless and firms can freely shift production from one good to another without delays. But time lags do occur in shifting production, transactions are costly, and competition is imperfect in many lines of commerce. As a result, the actual market allocation of resources is somewhat less efficient than allocations in the perfect competition model.

32 The example assumes that the two methods. of dispute resolution are identical products from the consumer's viewpoint.

33 See Rosenberg \& Sovern, Delay and the Dynamics of Personal Injury Litigation, 59 CoLum. L. REv. 1115,1139 (1959).

34 Delay is not due to the fact that the demand for litigation is high and the amount of judge time limited. The demand for potatoes is also high and the capacity to expand production to meet new increments of demand also limited. People queue up to buy litigation but not to buy potatoes because judicial time is not rationed by price and potatoes are. ... If the prices necessary to clear the market (eliminate the queue) were very high, it would be a signal that an investment of resources in hiring more judges would probably be cost justified. The prices might not be high. Perhaps only' a small fraction of litigants have sufficient interest in an early trial to pay a surcharge. . . . But we will never know in the absence of a price mechanism for measuring the intensity of demand.

R. POSNER, supra note 29, at 355 (emphasis added). See generally Robinson, supra note 30; Stockfisch, supra note 30.

35 See generally Vandermuelen, supra note 30. 
derive from a service with its cost. When services are free, ${ }^{36}$ consumers are not forced to make this comparison; they have no incentive to conserve resources, because additional consumption costs nothing. Thus, fees reflecting the real cost of providing court services would help deter waste.

The second goal of an effective fee system, consonance with social policies, derives from the general proposition that all state policies and state actions should be coordinated in order to maximize citizen welfare. Court fee systems should therefore not conflict with social policies established by legislation, through court decisions, in state constitutions, or through implicit popular consensus.

Finally, an effective fee system must be administratively feasible. Fee systems generate various operating costs-for example, fees must be collected, recorded, and deposited in a bank. Although economists often simplify their analysis by ignoring operating costs, ${ }^{37}$ a practical appraisal of fee systems requires consideration of these costs.

\section{Effectiveness of Current Fee Systems}

The most effective fee system would maximize each of the three general goals. Yet these goals may often conflict, ${ }^{38}$ and no fee system can maximize all three simultaneously. Evaluating the effectiveness of particular characteristics of fee systems thus requires not only an analysis of each characteristic's effect on each goal, but also of its effect on the interaction among goals.

\section{A. Effectiveness of Common Characteristics of Multiple and Single Fee Systems}

1. Nominal Fees. As noted earlier, ${ }^{39}$ fees that reflect only a small portion of actual court costs can interfere with resource allocation by making courts more attractive than alternate dispute resolution services

36 A good may be considered free not only when its initial distribution is without charge, but also when it is available in unlimited quantities at a fixed price. In the latter instance, consumption may be considered free because it costs an individual who has paid the fixed fee nothing to consume additional quantities of the good.

37 See Davies, supra note 30, at 158-60.

38 For example, the fee system that best allocates resources may have a high administrative cost, and a system that completely eliminates waste may conflict with established policy. For each conflict, competing social policies must be balanced to determine, for example, if a $\$ 500,000$ annual savings in administrative cost would be worth denying relief to 500 plaintiffs per year. These conflicts must be resolved by balancing the various goals. The resolution is usually accomplished through the political process, but some conflicts can be resolved mechanically if the alternatives can be reduced to dollar cost comparisons.

39 See text and notes at notes $32 \& 36$ supra. 
with lower real costs. Nevertheless, such distortion arising from subsidization may be justified if promoting certain social policies is considered more important than achieving appropriate allocation of resources.

One-policy furthered by subsidization of litigation is society's interest in assuring the trial of a sufficient number of cases to develop and enforce rules of conduct. ${ }^{40}$ Society may also consider market distribution of court services inappropriate, given the special nature of those services. Unlike most market goods or services, which are simply property, courts are a means of preserving rights in property. ${ }^{41}$ Subsidization helps assure all citizens equal access to the courts to protect those rights. ${ }^{42}$ A third social policy supporting subsidization is the maintenance of state control over dispute resolution. If courts are not subsidized, litigants may choose other less costly means of dispute resolution, such as arbitration or self-help. Assuming a strong social interest in confining most dispute resolution to the courts, a system of nominal fees may be effective even though the resulting inappropriate allocation of resources is costly.

2. Statutory Establishment of Fees and Service Levels. Courts operate in a dynamic environment in which exogenous shocks may change the demand for litigation and the cost of providing court services. ${ }^{43}$ Setting fees and service levels by statute interferes with resource allocation

$40[T]$ he allocative function of the legal system suggests a possible economic justification for government's defraying a portion of the costs of the system .... If the function of the legal system were solely to settle disputes, it would be appropriate to impose the entire costs of the system on the disputants. But that is not its only function. It establishes rules of conduct designed to shape future conduct, not only the present disputants' but also other people's. Since the social benefits of a litigation may exceed the private benefits to the litigants, the amount of litigation might be too small if the litigants had to bear the total costs of the suit.

R. POSNER, supra note 29 , at $322-23$.

Governments may thus subsidize courts, reducing fees to the level at which the amount of litigation demanded produces just enough social benefits to satisfy society's demand for these benefits. Resource allocations in this scheme could still be determined by the market; the government would effectively lower the price through subsidization and induce the market to allocate more resources to courts than it would absent subsidization.

41 Michelman, Access Fees, supra note 2. In an earlier work, Professor Michelman explored the notion that access to courts may be a "just" or "basic" want that all citizens may demand on equal grounds. Michelman, Protecting the Poor, supra note 2, at 13.

42 The number of citizens with access is a function of the size of the subsidy. The value of access, of course, may be undercut by long delays in processing claims that must receive prompt consideration.

43 A change in legal doctrine, such as the move toward strict products liability, can cause shifts in demand for legal services. See Casper \& Pósner, $A$ Study of the Supreme Court's Caseload, 3 J. LEG. STudies 339, 346-49 (1974). Similarly, fluctuations in the cost of inputs, such as labor, can change the cost of providing court services. 
by impeding adjustment to these changes. Statutes authorizing courts to establish and modify fees can alleviate this problem, because courts can adjust fees with minimal delay ${ }^{41}$ and can generally behave as a private firm in setting prices. ${ }^{45}$

When legislatures control fee systems, the administrative cost is high; decision making requires the time of many individuals and the resources of the legislative process. Administrative decision making, by contrast, is typically less time consuming and involves fewer individuals. If there were significant advantages to legislative decision making, the additional costs of the legislative process could be justified; but legislative decision making on court fees has few advantages.

3. Prepayment Requirement. The administrative cost of requiring prepayment of court fees is considerably less than the administrative cost of deferring fee collection until the dispute is resolved. A prepayment requirement places court operations on a cash basis and does not require the states to extend interest-free credit to litigants. Moreover, since most cases are resolved before trial, ${ }^{46}$ filing may be the only convenient time to collect the fee. Delayed collection is costly; the state must locate the parties who settle or fail to prosecute and may be forced in some cases to take legal action to collect fees or to write off a portion of fees as uncollectible. A prepayment requirement is a more efficient collection procedure.

4. Fee Burden on the Losing Party. Placing the final burden of fees on the losing party may cause a misallocation and a waste of resources. In purchasing court services that may be demanded by one party without the consent of the other, a litigant will evaluate his cost not by the amount of the fee, but rather by the amount of the fee discounted by his estimate of the probability that he will win. ${ }^{47}$ The

44 For examples of statutory schemes in which the authority to set fees is delegated to the courts, see note 23 supra.

45 The courts could simulate the behavior of a private firm in a competitive market by setting the price of court services equal to their marginal cost. If the courts acted as a private monopolist, however, they would maximize net revenues by setting prices above marginal costs, providing fewer services, and reaping monopoly profits. This would be an inefficient allocation of resources. See R. POSNER, supra note 29, at 104-07.

46 In fiscal years 1969 through 1971, 257,910 civil actions were filed in the United States district courts. 1972 DIR. ADM. OFF. U.S. CTS. ANN. REP. 119 [hereinafter cited as 1972, REPORT]. Yet during fiscal 1970-72, civil trials totalled only 30,504. Id. at 159. This indicates that in federal courts, approximately 11.4 percent of cases filed proceed to trial.

47 For example, a litigant who believes he has a 25 percent chance of winning his case will consider a $\$ 100$ jury fee to cost only $\$ 75$. The litigant will calculate his cost as the amount of the fee multiplied by the probability of paying it, in this case $\$ 100 \times .75$. 
apparent cost will always be lower than the actual fee, ${ }^{48}$ thus causing litigants to purchase more optional services than if the apparent cost were equal to the full amount of the fee. A litigant who is virtually certain of winning may request court services with impunity, since he knows he will not have to pay for them.

Conversely, assessing the losing party all fees may encourage conservation of resources. First, the rule might prompt potential losers to settle out of court, decreasing the number of trials. Second, it may foster conservation by forcing those contemplating wrongful acts to consider court fees as part of the cost of their prospective actions. ${ }^{49} \mathrm{~A}$ rational man will commit an act only when its benefits exceed its costs. Incorporating court costs into the cost-benefit analysis may encourage a would-be wrong-doer to forego the wrongful act. ${ }^{50}$

5. Provisions for Indigent Litigants. Waiving court fees for indigents presents several problems. First, exempting indigents from payment of fees reduces their incentive to conserve resources. ${ }^{51}$ Waiver of fees allows indigents to litigate nominal or frivolous claims, ${ }^{52}$ while others are deterred by fees from litigating similar claims. Second, administering waiver provisions is costly because it requires the use of judicial time, the scarcest resource of the legal system, to determine whether a claimant qualifies for the waiver. ${ }^{53}$

Waiver provisions may be justified, however, by social policies favoring equal availability of services to all citizens ${ }^{54}$ or a redistribution of wealth. 55

48 This assertion will be valid for every litigant who perceives some probability of winning his case.

49 This discussion assumes, of course; that parties contemplating wrongful acts are deterred, to some degree, by the legal system's sanctions. This may be less true for civil than for criminal acts, since an individual may be less able to predict whether his act is civilly actionable than whether it violates a criminal statute.

50 Economists have suggested that rules of tort and contract law do not prevent commission of all wrongful acts, but only those that are not cost-justified. See generally Brown, Toward an Economic Theory of Liability, 2 J. LEG. STUdies 323 (1973).

51 See text at note 35 supra.

52 Bringing suit will cost the indigent only his time if attorney's fees and other legal services are provided without charge. Prescreening by judges and legal aid services may eliminate frivolous suits brought to harass another party, but it will not eliminateand probably is not designed to eliminate-valid suits with relatively inconsequential stakes. The usual standard is the merit of the case, not whether it economically justifies an investment of resources.

53 At least one judge has lamented the time-consuming nature of those decisions. Duniway, The Poor Man in the Federal Courts, 18 StAN. L. REv. 1270, 1286 (1966).

54 See text at note 42 supra.

56 Distribution of services in kind may be a less efficient means of equalizing the distribution of wealth than comprehensive tax or grant programs. These latter programs 


\section{B. Multiple Fee Systems}

By selling each service separately, a multiple fee system provides information that permits administrators to measure litigant demand for each service and allocate resources accordingly. ${ }^{5 B}$ A pure multiple fee system would be most efficient, because it provides this information for all court services. Existing multiple fee systems are less efficient, because they do so for only a limited number of services. ${ }^{57}$ This inefficiency may be offset to some extent, however, by a social policy that certain components of court services, such as the jury ${ }^{58}$ or the trial itself, are inappropriate for market distribution. ${ }^{59}$

A multiple fee system effectively allocates and conserves resources only if its fees reflect actual costs. Those costs include not only the costs of the services provided, but also the administrative costs of the fee system itself. ${ }^{.0}$

\section{Single Fee Systems}

Although the pure single fee system is easy to administer and relatively inexpensive, it interferes with efficient allocation and conservation of resources because it ignores differential utilization of court services. A pure single fee system does ration consumption of court services; litigants are encouraged to use more services than if separate payment were required for each. ${ }^{01}$ This problem has led to divergence from the pure system; many existing single fee systems isolate certain items, such as juries, and charge separately for them. ${ }^{.2}$

would involve a more uniform redistribution of wealth, since waiver of court fees affects only indigents who demand court services.

56 See text at note 33 supra.

57 Trial-related services, which are usually not charged for separately, cost hundreds of dollars. See 1973 Jud. Councrl, of CAlIF. ANN. REP. 106 (\$665 daily cost for civil jury trial excluding jury fees); K. LAU, supra note 5, at 7 (\$750 per day, New York state jury trial); Reardon Civil Docket Congestion-A Massachusetts Answer, 39 B.U.L. Rev. 297,303 (1959) ( $\$ 650-\$ 750$ daily cost for jury trial).

58 Jury fee statutes have been assailed periodically, see Knee v. Baltimore City Passenger Ry., 87 Md. 623, 627, 40 A. 890, 892 (1898), usually on the ground that they violate the right to trial by jury guaranteed by the seventh amendment or similar provisions in state constitutions. Yet courts have consistently held that the right is "not a right to command the services of a jury without cost but is of the same nature as the right to have official services performed by public officers, and a requirement for the payment of a reasonable amount for jury fees ... is not a denial or encroachment upon the right." Morrison Hotel \& Restaurant Co. v. Kirsner, 245 Ill. 431, 433, 92 N.E. 285, 286 (1910); accord, Conneau v. Geis, 73 Cal. 176, 177, 14 P. 580, 581 (1887); People ex rel. Flanagan v. McDonough, 24 III. 2d 178, 180-81, 180 N.E.2d 486, 487 (1962).

59 Cf. Michelman, Protecting the Poor, supra note 2, at 13.

60 See text and notes at notes 32-37 supra.

01 See text and notes at notes 35-36 supra.

62 See text and notes at notes 13-17 supra. 
Separate trial fees, however, may deter parties who have filed suit from proceeding to trial. This deterrent effect would conflict with the state's need for trials to establish rules of conduct and with its interest in monopolizing dispute resolution.

\section{The Optimal Fee System}

As noted earlier, ${ }^{63}$ conflicts exist among the general goals, and no fee system can accomplish all three goals simultaneously. An optimal system could nonetheless be defined if a common unit of measure could be applied to each goal; the optimum would then be attained by maximizing the single summed value of all the goals. Unfortunately, no common measure can be applied to these goals, because each goal has two effects, only one of which can be objectively measured. The first effect is on real costs, which are lowered, for example, when a system of greater administrative feasibility or more efficient resource allocation is instituted. The second effect is on social costs, which are lower, for example, in a system that furthers a social policy of redistributing wealth. The first effect is tangible and can be objectively evaluated, but the second effect is intangible and amenable to only subjective evaluation. Thus, although it is impracticable to define an optimal system with respect to total costs, both real and social, it would be possible to define an optimal system with respect to real costs alone. This optimum would exist when real costs are minimized.

Implementing this theoretical concept is not easy; it is unlikely that an optimal system could actually be devised and put into use. The preceding analysis of multiple and single fee systems, however, suggests one means of minimizing real costs. As that analysis indicated, single fee systems tend to sacrifice conservation and allocation benefits to attain savings in administrative cost, while multiple fee systems tend to sacrifice administrative cost savings to attain conservation and allocation benefits. By breaking apart some of the services sold as a unit under the single fee system, and by grouping and selling as a single unit some of the services sold separately in the multiple fee system, it may be possible to develop a new system that operates at a lower net real cost than either existing system. The problem is one of creating bundles of services that are highly associated, in that litigants who purchase one service are likely to purchase all other services within the group as well.

Ascertaining the degree of association among various court services is difficult, ${ }^{64}$ but one modification in court fee systems is suggested by

63 See text and note at note 38 supra.

64 For example, factors such as the complexity of a particular cause of action or the number of parties involved can cause wide variations in the use of court services. 
a basic pattern of association among court services. First, all litigants utilize pretrial services, such as those related to filing and docketing an action. An individual who purchases one pretrial service is likely to purchase all such services. But a relatively small number of litigants reach trial, and there is wide variation in their use of trial-related services. ${ }^{65}$ A fee system could become more effective by utilizing two fees based on these patterns of association. ${ }^{68}$

The first fee would be an entry fee, similar to a filing fee, and would cover all pretrial services. Since the additional nontrial services available to a litigant after filing are relatively few and relatively inexpensive, use of a single fee reflecting the average costs of pretrial processing would not significantly encourage waste or misallocation of resources.

The second fee would apply only to litigants who proceed to trial. Unlike the entry fee, which would be the same for all cases, the trial fee would vary with the length of the trial and the use of a jury. A fixed rate for each day or half day of trial, supplemented by a surcharge for use of a jury, would probably be most efficient. Although this system would be more costly to administer than one utilizing a single fixed trial fee, the additional cost would be justified, because the system would conserve court resources by discouraging unnecessarily lengthy trials. ${ }^{67}$

\section{CONCLUSION}

An analysis of court fee systems and their three general goals-allocation and conservation of resources, consonance with social policies, and administrative feasibility-suggests that an effective fee system would group all court services into two bundles. Services from the time of filing until trial would be purchased with a single fee common to all cases; a second fee would cover trial services, varying with the length of trial and the use of a jury. This system combines the resource allocation and conservation characteristics of a multiple fee system with the administrative efficiency of a single fee system.

The high cost of deferred collection of the fee for pretrial services justifies a prepayment requirement. If the plaintiff prevails, however,

B5 1972 REPORT, supra note 46 , at 159 . This is indicated by the duration of the 18,700 civil actions tried in United States district courts during fiscal 1972: 27.7 percent of the actions were tried in less than one day; 25.8 percent lasted one day; 22.4 percent lasted two days; 10.5 percent lasted three days; 12.1 percent lasted between four and nine days; and 1.5 percent lasted ten days or more.

B6 At least one jurisdiction has incorporated this pattern into its fee system. See note 19 supra.

67 Litigation costs other than court fees will be considerable in most cases, and thus will also deter the unwarranted use of additional trial resources. 
the judgment should include prepaid fees. Assessment of the trial charge must necessarily await the end of the trial, when it would be collected from the losing party. Placing the fee burden on the losing party is justified on efficiency and policy grounds.

Nicholas A. Perensovich 